\title{
Control of physicochemical parameters of spring waters near quarries exploiting limestone rock
}

\author{
Ghizlane Fattah ${ }^{1, *}$, Fouzia Ghrissi $^{1}$, Jamal Mabrouki $^{2}$, and Mohamed Kabriti $^{3}$ \\ ${ }^{1}$ Water treatment and reuse structure, Civil hydraulic and environmental engineering laboratory, Mohammadia School of Engineers, \\ Mohammed V University of Rabat, Avenue Ibn Sina B.P 765, Agdal Rabat, 10090 Morocco \\ ${ }^{2}$ Laboratory of Spectroscopy, Molecular Modeling, Materials, Nanomaterial, Water and Environment, CERNE2D, Mohammed V \\ University in Rabat, Faculty of Science, Avenue Ibn Battouta, BP1014, Agdal, Rabat, Morocco \\ ${ }^{3}$ National Laboratory for Pollution Studies and Monitoring, Avenue Mohamed Ben Abdellah Erregragui Madinat Al-Irfane. Rabat, \\ Morocco
}

\begin{abstract}
The goal behind this work is defined as the study of the quality of water from karst springs near quarries exploiting limestone rock in order to assess its adequacy with domestic uses. At that end, a study at the mountain level was carried out. This mountain is in the Haouz area, in Tetouan, which is located north of Morocco and shelters active quarries. This research is based on the assessment of the physico-chemical parameters of the spring water used by local residents and located near this industry. The water quality evaluation was carried out by comparing the recorded values, according to Moroccan Standards related to the quality of water for human use. The review of some parameter's indicative of water pollution $\left(\mathrm{T}^{\circ}, \mathrm{pH}\right.$, electrical conductivity, dissolved oxygen, turbidity, total dissolved solids and the alkalimetric total title) revealed that the quality of the studied spring water is good and does not present any health risk to the users of this water during the winter season.
\end{abstract}

\section{Introduction}

Nowadays, the main source of drinking water in urban and human areas comes from underground resources, that plays a vital role in the existence of human society that depends directly on it [1]. Several societal factors such as the industrialization, the modernization of civil life and the population explosion have contributed to the swift deterioration of these groundwater resources [2, 3]. However, no awareness of the gravity of this phenomenon has been observed in a majority of emerging countries. These countries, unfortunately, continue to produce huge quantities of anthropogenic pollutants.

Nevertheless, Morocco has been experiencing, these recent years, a remarkable progress in the infrastructure and urban development sectors. The extraction sector has also grown rapidly due to the need for a guaranteed supply of raw materials [4].

The extraction of these raw materials, which are fundamental for the economical development and the survival of a given field, is not inconsequential, in fact, it generates direct and significant pollution of groundwater. This pollution is inevitable, if the exploitation takes place mainly above an aquifer or in its vicinity.

Limestone is one of the main raw materials used in the construction industry. Cement and aggregates are obtained by the crushing process of freshly extracted limestone rocks
In the Tangier-Tetouan region, one of the main sources for the production of cement and aggregates is the Haouz range. Which is distinguished by its abundance of limestone rocks and also by its geographic location close to the major markets in this area. This region is experiencing significant socio-economic development and is considered to be the focal point in terms of the dissemination of extraction activities.

However, this secondary range of Haouz also composes an important karstic spring, sheltering important resurgences of water that is considered crucial for the supply of drinking water of a large part of the population of rural areas and also essential to the survival of the agricultural activity at these region [5].

It is important to emphasize that these resurgences of water are vulnerable to all sorts of pollution, whether it comes from the physical environment in which the water has evolved or caused by human intervention.

Protecting these resources mainly requires increased qualitative monitoring of the waters and also good management of the development of the territory on the surface [6].

As mentioned above, increased monitoring of groundwater quality requires in-depth physico-chemical analysis, as it is often the case for public health studies, which are an incorporated part of the environmental pollution studies [7].

Therefore, the present study aims to control the physico-chemical quality of spring water nearby a quarry 
cottage located in the Haouz aquifer. With this aim in mind, two sampling campaigns were carried out in December and January 2019. Physico-chemical parameters measured in situ and were adopted in the laboratory for the characterization of these waters.

\section{Description of the study area}

The study area is located north of Morocco, more precisely on the limestone chain of Haouz. This chain, which is extended from Ceuta to Tétouan, constitutes the frontal part of the internal domain of the Rifaine chain and is mainly composed of carbonates. It is in the form of a strip about thirty kilometers long and 1 to $4 \mathrm{~km}$ wide. This chain with a total area of $134 \mathrm{~km}^{2}$ includes the Jbel Haouz massif, culminating at $838 \mathrm{~m} \mathrm{NGM}$ and the Jbel Dersa massif, dominating the city of Tétouan [8].

From a geological point of view, the Haouz chain is a complex tectonic unit composed of several fragmented and nested structural units. These units are mainly made up of limestone and dolomite from the Triassic and Early Jurassic, and are cut by multiple transformations. This chain is surrounded by impermeable or not very permeable series: external flyschs in the West, Paleozoic shales in the East [9].

Its Mediterranean-type climatic context is characterized by two well-differentiated seasons, a wet and cool season, the annual precipitation is around $600 \mathrm{~m}$ at low altitude and over $1000 \mathrm{~mm}$ over the high reliefs of the limestone chain (from October to April, the precipitation is more than $92 \%$ of its totality), and another dry and relatively warm season (May-September) [10].

Hydrogeologically, the carbonate formations forming the backbone of this chain play a very important role in the water cycle of the Rif area. Their relatively large area, their encasement between poorly permeable series, the significant precipitation of which they are the seat, their altitude, their karstification are all favorable elements to the storage of large quantities of water which are only returned to flowa after a certain delay; they are therefore the seat of perennial flows, very rare in the Rif, and thus ensure the summer supply of the rivers which cross them, as well as the corresponding alluvial aquifers [9].

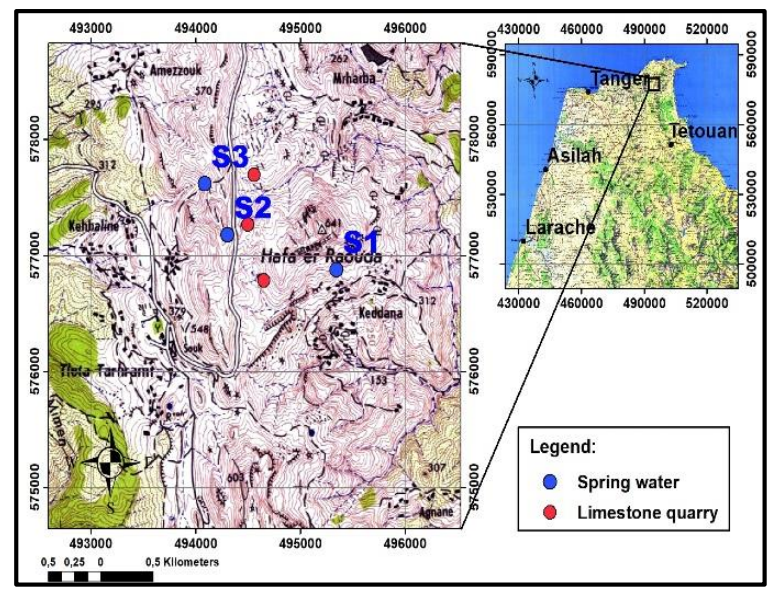

Fig. 1. Location of sampling points (Tangier topographic map 1: 250000)
This karst system is characterized by concentrated infiltration and rapid transfers into the aquifer lead to rapid changes in water chemistry, and therefore in the quality of water at the outlet of karst systems after rainy events [11].

\section{Materials and methods}

\subsection{Sampling}

The spring water sampling points were selected based on their availability and their proximity to the quarry cottage.

For the physico-chemical analyzes that must be carried out at the bench, three water samples were taken from each source during 2 measurement patterns (December and January 2019). These samples were placed in plastic bottles and were then transported to the National Laboratory for Pollution Studies and Monitoring (LNESP). A total of 9 water samples were taken.

The conservation of water samples refers to the protocol defined by the French Agency for Standardization Afnor NM ISO 5667-3 [12].

\subsection{Physico-chemical analyzes of water}

The physico-chemical parameters were monitored according to the techniques of Rodier [10]. Analyzes covered temperature $\left(\mathrm{T}^{\circ}\right)$, hydrogen potential $(\mathrm{pH})$, salinity, dissolved oxygen $(\mathrm{O} 2)$, electrical conductivity (Cs) and total concentration of dissolved substances (TDS) which were measured in situ in order to avoid alteration of the characteristics of the sample by immersing a professional multi-parameter analyzer HANNA HI 9828 in $50 \mathrm{ml}$ of water taken from each source.

However, the analysis of the parameters in particular; the turbidity and the complete alkaline titer were determined respectively according to the method described in AFNOR T90-033 [12] and the method by volumetric assay with hydrochloric acid (at $0.02 \mathrm{~mol} / \mathrm{L}$ ) poured to measure the $\mathrm{CO} 32$ - and $\mathrm{HCO} 3$ - ions contained in $100 \mathrm{~mL}$ of water sample, in the presence of the green of the bromocresol-rhodamine.

\section{Results and discussion}

\subsection{Characterization of sampling points}

The choice of site was mainly justified by the presence of a group of active quarries not far from the spring waters exploited for the human consumption by neighboring residents and by passers-by using the provincial road RP4703.

The three chosen samples points are symbolized by $\mathrm{S} 1, \mathrm{~S} 2$ and S3 (Figure 1):

$\checkmark$ S1 is spring water located $720 \mathrm{~m}$ east of the quarry group; 
S2 is spring water located $95 \mathrm{~m}$ west of the quarry group;

$\checkmark$ S3 is spring water located $164 \mathrm{~m}$ west of the quarry group.

\subsection{Physico-chemical characterization of water}

The results of measurements of different parameters are presented below. Their representation of every parameter makes it possible to better expose any variations and can facilitate the interpretations.

\subsubsection{Temperature $(T)$}

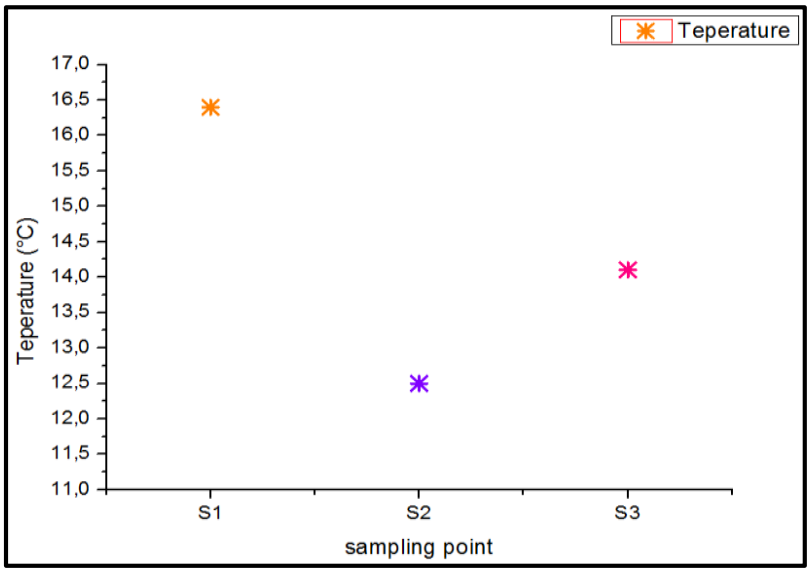

Fig. 2. Results of the temperature

Water temperature is a fundamental and critical physical factor in the aquatic environment, as it governs almost all physical, chemical and biological reactions [12].

As shown in figure 2 , in the study area, with a temperature that varies between $12.5^{\circ} \mathrm{C}(\mathrm{S} 2)$ and $16.1^{\circ}$ $\mathrm{C}(\mathrm{S} 1)$, this parameter remains acceptable for Moroccan portability standards $\left(5^{\circ} \mathrm{C}<\mathrm{T}<25^{\circ} \mathrm{C}\right)$.

\subsubsection{Hydrogen potential $(\mathrm{pH})$}

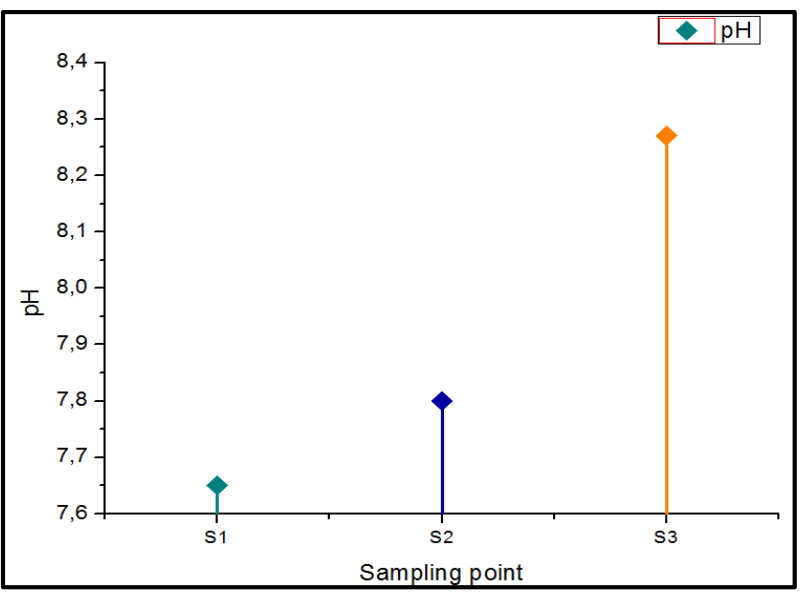

Fig. 3. Results of the hydrogen potential

The $\mathrm{pH}$ is an important parameter indicating the acid or basic character of the water. In groundwater. It is also influenced by the geological nature of the drainage basin, acid precipitation, biological activity and certain industrial discharges [13]. Changes in $\mathrm{pH}$ in groundwater follow those in surface water, with ever lower values

As mentioned above in figure 3 , the $\mathrm{pH}$ values at the point level vary between 7.65 and 8.27. In general, the $\mathrm{pH}$ is within the standard of potability which varies between 6.5 and 8.5 [14].

\subsubsection{Electrical conductivity (EC)}

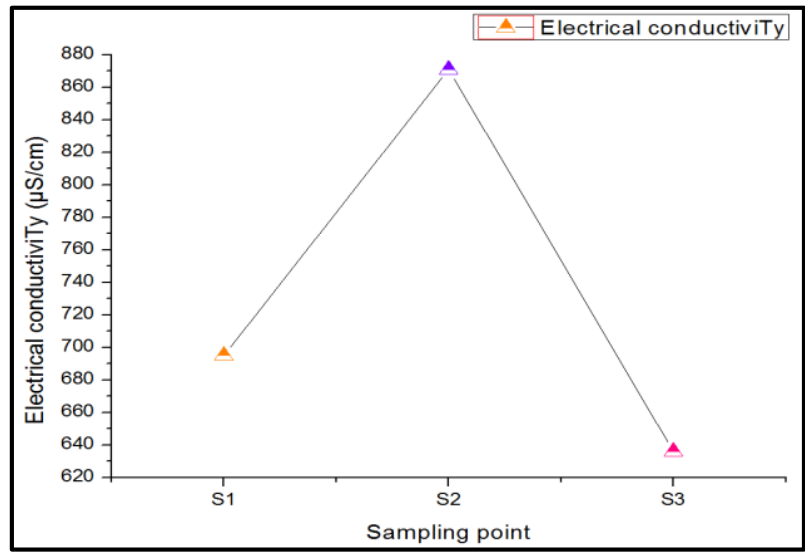

Fig. 4. Results of the Electrical conductivity

Variations in conductivity imply changes in the chemical composition of water, as well as lesser variations express an acceleration or a slowing down of the bacterial processes of mineralization of organic matter [15-17].

As illustrated in figure 4 , it is noted that the value of the conductivity (varies between 636 and $871 \mu \mathrm{S} / \mathrm{cm}$ ) in all sources, it is lower than the standard of potability (NM 037001). The nearest sampling point to active quarries has increased mineralization.

\subsubsection{Total Dissolved Solids (TDS)}

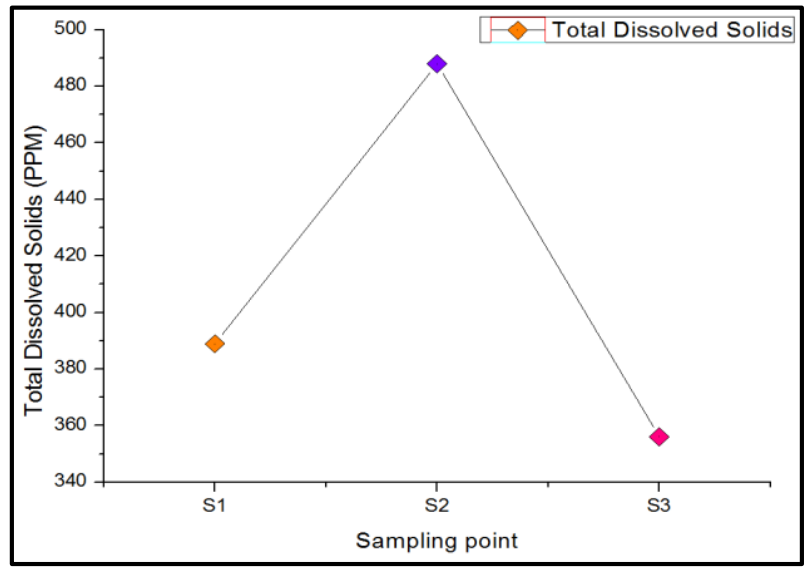

Fig. 5. Results of the Total Dissolved Solids

The total concentration of dissolved substances refers to total organic or inorganic dissolved solids in particular; minerals, salts, metals, bacteria, viruses, heavy metals, cations or anions dissolved in water.

Moroccan regulations (NM 003.7.01) do not impose a standard for the total concentration of dissolved 
substances, but according to WHO standards, the values must be below 1000 ppm.

In this analysis, the TDS recorded a maximum value of $488 \mathrm{ppm}$ which complies with the standards of potablity, see figure 5 .

\subsubsection{Dissolved oxygen (O2)}

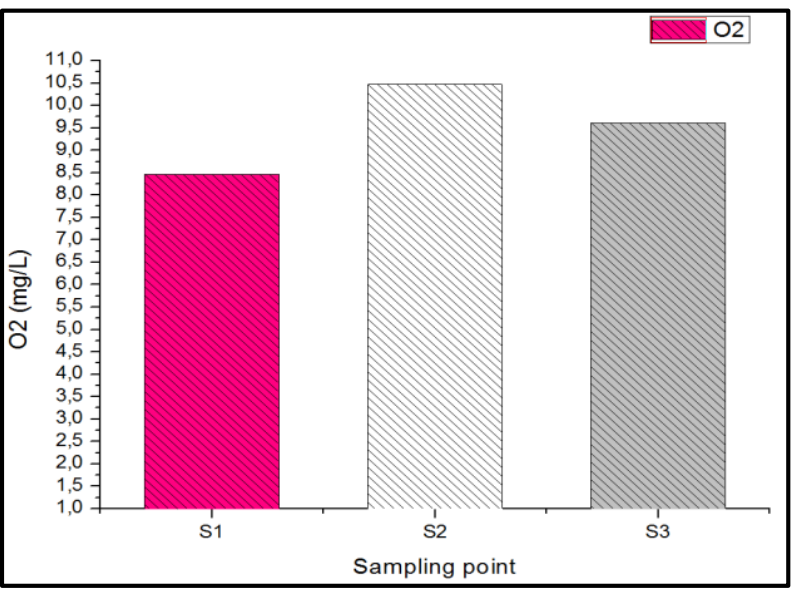

Fig. 6. Results of the dissolved oxygen

Water absorbs as much oxygen as necessary so that the partial pressures of oxygen in the liquid and in the air are in equilibrium. The solubility of oxygen in water is a function of atmospheric pressure (altitude), temperature and mineralization of the water.

The concentration of dissolved oxygen is an essential parameter in the maintaining of life, and therefore in the phenomena of degradation of organic matter and photosynthesis.

The recorded oxygen values shown in figure 6 , illustrate a good level of oxygenation in the waters of all the controlled points which confirms that in karst aquifers, the good connections with the atmosphere imply oxic waters at the outlet of karst systems [18].

\subsubsection{Turbidity}

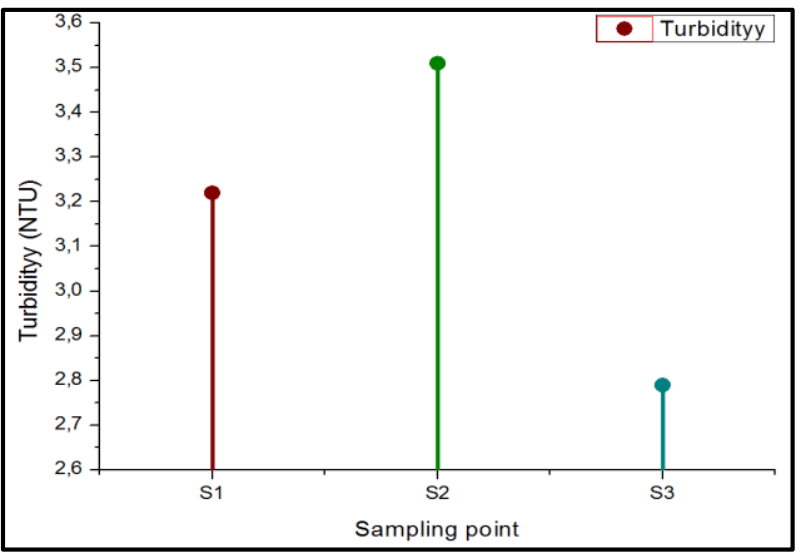

Fig. 7. Results of the turbidity

Turbidity is an organoleptic parameter and an expression of the optical properties of water to absorb or / and diffuse light. This reduction in the transparency of a liquid is due to the presence of suspended matter of mineral origin (clay, silt, sand ...), micro particles and microorganisms.

As explained by figure 7 , the turbidity varies from one station to another but it remains below the maximum authorized by the standard quality of the water supply which is $<5$ NTU.

\subsubsection{Titre alcalimétrique complet (TAC)}

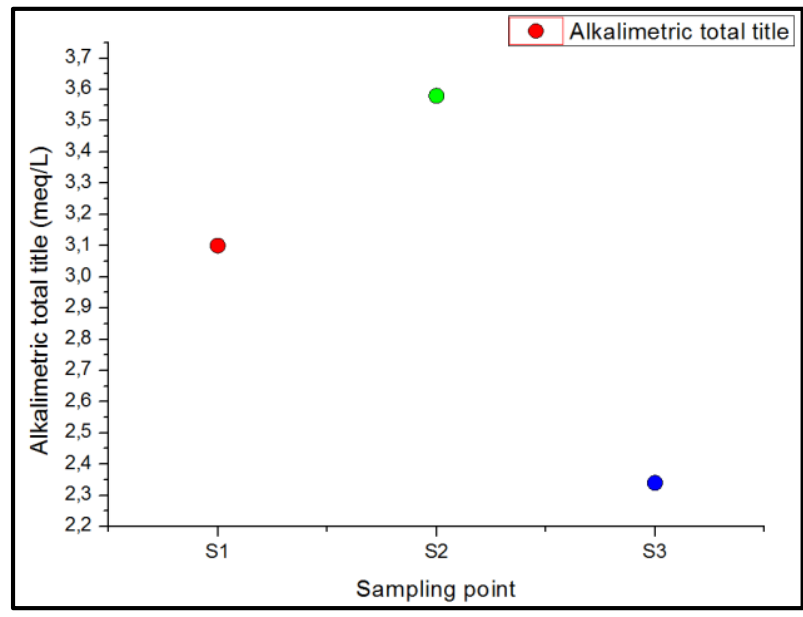

Fig. 8. Results of the alkalimetric total title

The alkalimetric total title corresponds to the water content of free alkalis, carbonates and hydrogen carbonates which neutralize acids and bases in water and therefore limit the variations of $\mathrm{pH}$. These substances originally come from the calcareous substratum.

Moroccan regulations (NM 003.7.01) do not impose a standard for alkalinity, but the latter poses a problem of taste and scaling if C> $200 \mathrm{mg} / 1$. For this purpose, we can consider that the values recorded $3.1 \mathrm{mEq} / 1$ in $\mathrm{S} 1$, $3.58 \mathrm{mEq} / 1$ in S2 and $2.34 \mathrm{mEq} / 1$ in $\mathrm{S} 3 \mathrm{mEq} / 1$ present a normal content with a small variance between them. The slight increase observed at the $\mathrm{S} 1$ and $\mathrm{S} 2$ stations due to their proximity to active quarries, see figure 8 .

\section{Conclusion}

The report of the analyzed parameters of water samples reveals that during the study period (winter season), the quality of the studied spring water is good and respects the quality limits of the Moroccan Standards (Quality of water for human consumption).

Nevertheless, the monitoring of the sanitary quality of water must be carried out during all year long, especially since the impact of seasonal changes on water quality has been widely documented [19]. Such as the rise in temperatures which reduces the levels of dissolved oxygen in the waters, the low precipitation which results in a less dilution of the pollutants, while the frequent heavy rains increases the content of matter in suspension and the turbidity [20].

Also, the adoption of deep analyzes (MES, COD, $\mathrm{BOD}, \mathrm{Cl}-, \ldots)$ are necessary to ensure that these spring waters are conform to the water intended for human consumption. 


\section{References}

1. R. Shyamala, M. Shanthi and P. Lalitha, E-J Chem., 5 (4), 924-929, 2008

2. R. Agrawal, RJC, 2(4), 969-971, 2009

3. J. Mabrouki, A. El Yadini, I. Bencheikh, K. Azoulay, A. Moufti, El S. Hajjaji, Hydrogeological and hydrochemical study of underground waters of the tablecloth in the vicinity of the controlled city dump mohammedia (Morocco). Adv. Intell. Syst. Comput. 913 (3), 22-33, 2019.

4. The official site of the Ministry of Transport Equipment and Logistics : www.equipement.gov.ma

5. S.Guergazi, S. Achour, Physicochemical characteristics of the supply of the city of Biskra waters. Practice of chlorination, Larhyss Journal, ISSN 1112-3680, 4, 119-127, 2005

6. P. Hugonin, Thematic introduction to water. University of Geneva, 1, 2011.

7. A Jafari, H. Mirhossaini, B. Kamareii, S. Dehestani, Asian J Appl Sci. 1, 87-92, 2008

8. Directif plan of water ressources integrated planning of the Loukkos, Tangier and Mediterranean Coast basins, 6, 33, 57, 2012

9. Editions of the geological service of Morocco, Water Resources of Morocco, Domains of the Rif and of Eastern Morocco, p 40, 45, 47- 48, 1971

10. K. El Morabiti., Y. El Kharim., K. Aluni, F.FdiL, M. Benmakhlouf, Hydrogeological and hydrogeochemical study of the main karst sources in the vicinity of the city of Tétouan, 59, 2009

11. Mahler et Lynch, 1999 ; Auckenthaler et al., 2002 ; Pronk et al., 2006 ; Heinz et al., 2009, Filippini et al., 2018 ; Schiperski et al., 2015a, 2015b ; Ender et al., 2018

12. D. Chapman, V. Kimstach, Selection of water quality variables. Water quality assessments: aguide to the use of biota, sediments and water in environment monitoring, Chapman edition, 2nd ed. E \& FN Spon, London., 59-126, 1996

13. A. Aït Boughrous, Biodiversity, ecology and groundwater quality two arid regions of Morocco, thesis for the Degree of Doctor, University Cadi Ayad, Morocco, 2007

14. W. Holser, G. Clement, L. Jansa, J Wade, Evaporites deposits of the north Atlantic rift. In:W. Manspeizer (editor), Triassic-Jurassic rifting. Continental breakup and the origin of the Atlantic Ocean and passive margins, Elsevier, Amsterdam, 525-556, 1988

15. J. Nisbet \& Vernaux, Chemical components of running water - Class discussions and proposals as a basis for interpreting chemical analyzes, Annales de limnologiesn, 6, 2, 161-190, 1970

16. P. Lavandier \& M. Mur, Use and partition of space and resources by tow coexisting Rhyacophilaspecies (Trichoptera) in hight montain stream, 1974

17. J. Giudicelli \& A. Cazaubon, Impact of the residual flow on the physical characteristics and benthic community (algae, invertebrates) of the regulated Mediterranean river: The durance, 1980
18. B.J. Mahler, R. Bourgeais, Dissolved oxygen fluctuations in karst spring flow and implications for endemic species: Barton Springs, Edwards aquifer, Texas, USA. Journal of Hydrology, 505, 291-298, 2013

19. S. Chakrabarty, H.P. Sarma, Climatic variables and its implications in ground water potability in Kamrupdistrict, Assam, India, Arch. Appl, 3, 265272, 2011

20. Groundwater Surveys and Development Agency, Government of Maharashtra; Central Ground Water Board, Central Region, Nagpur, Government of India, Report on the Dynamic Ground Water Resources of Maharashtra, 2014. 